\title{
Progesterone and Breast Cancer: an NCI Workshop Report
}

\author{
Neeraja Sathyamoorthy ${ }^{1} \cdot$ Carol A. Lange ${ }^{2}$ \\ Published online: 3 February 2020 \\ (C) This is a U.S. government work and not under copyright protection in the U.S.; foreign copyright protection may apply 2020
}

\section{Contributors}

Cathrin Brisken, cathrin.brisken@epfl.ch

Amy Dwyer, amy.dwyer@adelaide.edu.au

Dean Edwards, deane@bcm.edu

J. Dinny Graham, dinny.graham@sydney.edu.au

Christy Hagan, chagan@kumc.edu

Gordon Hager, hagerg@dce41.nci.nih.gov

Britta Jacobsen, Britta.jacobsen@cuanschutz.edu

Julie Kim, j-kim4@northwestern.edu

Sanaz Memarzadeh, smemarzadeh@mednet.ucla.edu

Carol Sartorius, Carol.Sartorius@ cuanschutz.edu

Thu Truong, thtruong@umn.edu

\section{Introduction}

The National Cancer Institute (NCI) held a workshop on "Progesterone \& Breast Cancer" in June 2018 that was cochaired by Drs. Carol Lange (University of Minnesota) and Seema Khan (Northwestern University). The overarching goal of the workshop was to bring together major players in the area to discuss the role of progesterone (P4) in the mammary gland and clarify controversies surrounding its activity in breast cancer. While it is known that adding a progesterone receptor (PR) ligand, either an agonist or an antagonist, in the presence of estrogen most often inhibits tumor growth in breast cancer cell models, $\mathrm{P} 4$ has also been shown to drive tumor heterogeneity and stem cell outgrowth. Furthermore, while P4 reduces tumor size in the early stages of disease, the sustained presence of $\mathrm{P} 4$

Neeraja Sathyamoorthy

sathyamn@mail.nih.gov

Carol A. Lange

lange047@umn.edu

1 Tumor Biology \& Microenvironment Branch, Division of Cancer Biology, National Cancer Institute, Rockville, MD, USA

2 Departments of Medicine and Pharmacology, Masonic Cancer Center, University of Minnesota, Minneapolis, MN, USA causes breast tumors to become more heterogeneous, and more plastic with an increased ability to migrate. Hence, the NCI workshop focused on addressing the role P4/PR plays in regulating multiple signaling pathways and the context in which PR acts to inhibit tumor growth versus its ability to drive tumor heterogeneity and stem cell growth. Below is a summary of the discussion among experts in the field who attended the workshop. Herein, we convey the content of the workshop followed by the major points of discussion with the permission of the attendees and identify areas for future studies on the topic of P4/PR in ER+ breast, endometrial, and other cancers that are influenced by $\mathrm{P} 4$.

\section{PR Isoforms}

PR isoforms have different binding sites in chromatin, and the coregulators associated with PR isoforms are different (1); more recent studies have expanded the repertoire of isoformspecific PR binding partners as measured by Rapid Immunoprecipitation Mass Spectrometry of Endogenous proteins (RIME) (2). Distinct but overlapping gene sets are regulated by two major PR isoforms which can form either homodimers or heterodimers at hormone-responsive elements in chromatin. PR-B (but not PR-A) primarily cross-talks with ER at estrogen-regulated genes via direct association as measured by co-IP and ChIP assays performed in human breast cancer cell lines and breast tumors (3), as well as in intact cells by proximity ligand assays (TH Truong and CA Lange unpublished data). The ER/PR interaction with c-Src kinase and hormone-dependent activation of downstream MAPKs was first defined by seminal studies in 1998 (4) and a role for ER/PR transcriptional complexes in the regulation of global gene expression was later demonstrated by gene profiling and RIME studies performed in breast cancer models $(2,3,5)$.

It is not known if both PR isoforms A and B are equally expressed in basal-like cancer stem cells in human breast cancer specimens. However, PR-B is a more potent proliferative isoform (in the absence of PR-A), while PR-A (in the absence of PR-B) is a more potent driver of stem cell-like phenotypes (6). While both PR isoforms can drive the formation of secondary 
mammospheres (also called tumorspheres) that are CD44+/ CD24-low and ALDH+ in vitro, PR-A+ breast cancer cell lines grown as spheres appear more basal-like (i.e., are more $\mathrm{CD} 49 \mathrm{f}+$ ), while PR-B+ breast cancer cell lines form fewer spheres that are $\sim 30 \%$ larger and more luminal-like (CD49f-low) (6). Evidence suggests that the ratio of PR-A:PR-B is disrupted in early carcinogenesis; atypical ductal hyperplasia, DCIS, and invasive disease all have higher PR-A expression relative to PR-B (7-9). Imbalanced PR isoform expression is also linked to poor endocrine therapy response. For example, the trans ATAC (Arimidex, tamoxifen alone, or in combination) cohort microarray showed that PR-A predominance predicted resistance to tamoxifen, but not anastrozole (10).

Although IHC-based detection of PR-A relative to PR-B isoforms in clinical samples is challenging (see the "Discussion" section), recent studies performed by Rojas et al. (11) reported that luminal A tumors tend to be PR-A rich, while more aggressive/endocrine-resistant luminal $\mathrm{B}$ tumors are PR-B rich. PR-A predominance may reflect the more rapid ligand-dependent downregulation of activated PR-B and/or greater sumoylation and increased stability of PR-A (12). The majority of cancer cells within a PR+ breast tumor express both isoforms (13); a nuclear aggregated or focal pattern of PR expression (i.e., activated PR) was associated with higher tumor grade/more advanced disease. Of note, the Clarke lab (Sydney) has published that certain anti-PR antibodies that detect both PRA and PRB on Westerns were unable to detect PR-B (and were therefore PR-A-specific) on IHC/IF of FFPE tissue. However, uncertainty may arise in staining of samples that are not fixed and processed in the same way as human tissues handled in a routine clinical pathology setting (e.g., cells fixed on slides, mouse tissues, fixed but not processed in the same way). Thus, it is true that a subset of PR monoclonal antibodies recognizes only the PR-A isoform in archival FFPE tissue (14). Additionally, PR monoclonal antibodies may preferentially recognize PR-A isoforms $(15,16)$ and weakly recognize selected post-translationally modified PR isoforms in archival formalinfixed paraffin-embedded (FFPE) breast cancer tissues (CA Lange, unpublished results).

\section{PR Mutations}

PR mutations in both the PR-B promoter and PR primary sequence have been described in the literature primarily for reproductive cancers. For example, $P G R$ gene polymorphisms (namely $+331 \mathrm{G} / \mathrm{A}$ and V660L SNP or PROGINS) that alter PR isoform expression or activity are associated with increased endometrial and ovarian cancers, while effects on breast cancer risk appear modest (17-20). It should be noted that results reported in the greater literature are relatively inconsistent, suggesting that more study is needed, especially in light of newer deep-sequencing technologies.
PR splice variant receptors have been described that exhibit constitutive DNA-binding activity $(12,21)$. Similar to ER, PR mutations have been identified in metastatic breast cancers ( $S$ Fuqua, unpublished data). Dr. Fuqua's team (Baylor College of Medicine, TX) has performed exon sequencing for all steroid receptors and their co-activators in paired primary tumors and metastatic lesions and found several novel as well as at least one previously published mutations in PR, namely the $P G R$ haplotype known as PROGINS that results in a V660L substitution in the PR hinge $(\mathrm{H})$ region that confers increased PR stability and expression (22). Both ER and PR expression varies widely in luminal breast cancer. $\mathrm{LOH}$ of the $P G R$ gene locus occurs with high frequency in breast cancer, as does loss of ER (23). Thus, while approximately $70 \%$ of newly diagnosed luminal type breast tumors are ER+/PR+, about $40 \%$ and $25 \%$ of these tumors exhibit loss of heterozygosity (LOH) at either the $P G R$ or ESR1 gene locus, respectively (5); ER and PR LOH are positively correlated. Despite this genetic loss, ER and PR mRNA levels remain very similar to that of diploid luminal tumors suggesting that other compensatory factors may exist in these tumors to maintain some level of ER and PR expression.

\section{Epigenetic Effects}

Differential methylation of the $P G R$ gene has also been reported. There are published studies showing that the PR-A promoter region was more frequently methylated (i.e., in a generepressed state) than the PR-B promoter region in TAMresistant patients (24). This finding is inconsistent with reports of PR-A dominance in luminal breast cancers and may reflect a change in PR isoform expression that occurs during late stages of endocrine-resistant tumor progression.

\section{PR Ligands}

Both E2 and P4 are effective (direct or indirect) breast mitogens and breast cancer risk is closely related to a woman's exposure to ovarian hormones (25). The role of PR and its ligands in breast cancer is also highly context-dependent. In terms of using P4 as opposed to synthetic progestins, researchers have used R5020 for two decades and have not observed any major differences between this synthetic progestin and P4 in their laboratories. R5020 is a more stable PR ligand relative to $\mathrm{P} 4$ since $\mathrm{P} 4$ is actively metabolized within the cell and R5020 is not. Deep sequencing studies have established that the effect of P4 is identical to that of R5020 (2). For the most part, P4 and progestins have similar biological effects except for medroxyprogesterone 17-acetate (MPA) which can also activate either GR (26) or AR (27) in biochemical assays conducted in vitro (as do many synthetic 
antiprogestins). Many of the synthetic progestins used clinically have androgenic effects, including those used as oral contraceptives. There is also a complete overlap in the transcriptional profiles of the high-affinity PR ligand ORG2058 (16a-ethyl-21-hydroxy-19-norprogesterone) versus $\mathrm{P} 4$ in T47D breast cancer cells (28).

Data indicates that norgestrel is also a dangerous progestin (i.e., agonist). A Finnish study (29) carried out a retrospective analysis of women diagnosed with breast cancer and their use of intrauterine norgestrel preparation for the treatment of menorrhagia (i.e., heavy menstrual bleeding). The study found that women who had used a norgestrel-releasing device had a higher and dose-dependent increase in risk. The precise health record maintained in the country lends considerable power to the study. Another large Danish study involving 1.8 million women, followed on average for about 10.9 years, demonstrated that oral contraceptives containing synthetic progestins increased breast cancer risk (30); this is dependent on the type of progestin and duration of use. This study has major implications for the role of progestins in breast cancer and may, in fact, be in part due to the androgenic effects of synthetic progestins that are widely reported $(31,32)$. However, a recent meta-analysis of worldwide epidemiological evidence supports the finding of increased breast cancer risk for women taking any form of progestin-containing HRT (33).

\section{PRs in Luminal and Lobular Breast Cancer}

Invasive lobular breast cancer (ILC) is the most frequent histological subtype after invasive ductal carcinoma (IDC). Compared with IDC, ILC tend to be (1) larger at diagnosis, (2) difficult to diagnose by mammography, (3) metastasize to unusual sites like the ovary and gastrointestinal tract, (4) poorer long-term outcomes, and (5) more highly ER+ and $\mathrm{PR}+(34,35)$.

Several lines of evidence suggest that PR is a driver of ILC. First, a study of 144 ILC tumors examining gene expression identified two main subtypes: an immune-related subtype and a hormone-related subtype. The latter had high expression of PR and its downstream signaling pathway is the main driver of this subtype (36). Another study examined the risk of different histological subtypes of breast cancer in women using hormone replacement therapy containing estrogen alone or E + a synthetic progestin $(\mathrm{P})$. The relative risk of ILC was higher in women taking $\mathrm{E}+\mathrm{P}$ versus $\mathrm{E}$ alone (2.0 versus 1.4 , respectively) (37). This indicates that progestins specifically increase the risk of ILC. Whether oral contraceptives increase the risk of ILC in women is controversial, however, the abovementioned Danish study shows increased risk of breast cancer in women using contraceptives containing progestin (30).

To date, all studies examining PR function in breast cancer have used IDC models. Two ILC cell lines (BCK4 and MDA-MB-134) that are ER+/PR+ have been used to study the function of PR in ILC where P4 increased estrogen-stimulated growth in vivo as measured by tumor volume and Ki67. Unlike in IDC, PR was not downregulated by $\mathrm{P} 4$ either in vitro or in vivo in models of ILC (37). P4 also influenced the organ sites to which ILC cells metastasized, as compared to IDC ((38); Britta Jacobsen, unpublished results). These studies reveal clear differences in biology between ILC and IDC.

Researchers have developed elegant breast cancer patientderived xenograft (PDX) models to test progestin therapies and mechanisms of ER or PR action $(39,40)$. ER+ PDX grown in Nod/SCID mice have a $20 \%$ take rate, and all require E2 to grow. Addition of P4 + E2 is typically inhibitory to PDX growth $(39,41)$. Single-cell RNAseq to segregate high PRexpressing from low PR-expressing cells demonstrated that most of the cells were of the luminal A subtype (C Sartorius, unpublished results). This is interesting because a common criticism of the PDX models is that they do not represent luminal A tumors. This may be a product of sequencing type and tumor heterogeneity. It also raises the issue as to whether the effects of progestins and/or anti-progestins are effective in the context of endocrine resistance? In the intraductal model, ER+ PDX grown in NOD/SCID mice have a $100 \%$ take rate and all of them grow without E2 supplementation (42) and the models reflect the biology of their clinical counterparts (43).

\section{Stem Cells}

PR-A is a potent driver of stem cell expansion in breast cancer models relative to PR-B, while of the two isoforms, is a stronger driver of proliferation in soft agar (6). These recently published data demonstrated that phosphorylation of PR Ser294 is required for breast cancer stem cell outgrowth as measured in tumorsphere assays and using a variety of breast cancer stem cell markers including CD44+/CD24- and ALDH (6). PR Ser294 phosphorylation is elevated when the same cells are subjected to $3 \mathrm{D}$ relative to $2 \mathrm{D}$ culture, as measured using specific antibodies and flow cytometry of permeabilized cells to detect minority PR+ subpopulations (AR Dwyer, TH Truong, and CA Lange, unpublished results). PR Ser294 phosphorylation is mediated by either $\mathrm{P} 4$ or growth factor (i.e., EGF) induced activation of MAPKs. Exogenously added $\mathrm{P} 4$ is not required for tumorsphere (mammosphere) formation (i.e., number) but contributes to increased tumorsphere size in defined media (6). While the combination of $\mathrm{E} 2+\mathrm{P} 4$ inhibited cell growth in soft agar, these hormones (alone or in combination) have no effect on secondary tumorsphere formation or the expression of stem cell markers (i.e., the ALDH+ and CD44+/CD24-low cell populations). While it is important to note that mammosphere media contains trace amounts of $\mathrm{P} 4$, this finding is relevant to postmenopausal women since both estrogen and P4 levels are low (i.e., women with ER+ breast 
cancer typically undergoes hormone-ablation). This contrasts with what is observed during pregnancy when levels of both hormones are high.

In primary cultures of normal breast epithelia, $\mathrm{P} 4$ stimulates cell growth by increasing progenitors. Primary breast cultures were sorted for enriched populations and it was found that PR transcripts were higher in the bipotent progenitorenriched compartment (44). Furthermore, P4 increases stem and luminal compartment, but decreases basal compartment, as measured by gene signature. Interestingly, while E2 also increases stem/luminal lineages and stem MetaPCNA index, combining E2 + P4 attenuates expansion of the stem cell compartment in cultures of normal breast epithelia (D Graham, unpublished results).

Both RANKL and Wnt4 are essential mediators of PR signaling during mammary gland development. Elegant data links Wnt4/RANKL and PR to stem cell signaling $(45,46)$. PR knockout mice form a ductal tree but no side branching; Wnt4 is required for side branching. Stem cell function can be assessed by serial transplantation into cleared mammary fat pad for seven generations. PR knock-out cells were only efficient to the first generation and Wnt4 knock-out cells were even less efficient than PR-/-, while RANKL-/- do not exhibit any alterations in mammary gland growth, side branching is inhibited. This was also seen in ex vivo experiments with tissue microstructures treated with P4 alone (46). Similarly, blocking RANKL signaling reduced P4-driven carcinogenesis in vivo, specifically in the early stages of tumorigenesis (47). P4 dramatically increased mammary stem and progenitor cell activity in the adult mammary gland (48). Further, RANK-/mice or denosumab-treated mice do not exhibit P4-induced mammary stem/progenitor cell expansion. They also fail to elicit a mammary Wnt response (47).

\section{Dosage and Route of Administration}

The dosage and route of $\mathrm{P} 4$ administration are very important and unfortunately, not always considered. Since the natural hormone, progesterone, is rapidly metabolized, researchers prefer to use R5020, a long-lived synthetic progestin that may provide more reproducible results.

Another key element of experimental design is the use of low- vs. high-dose $\mathrm{P} 4$ or progestins in in vitro studies-lowdose $\mathrm{P} 4$ can be proliferative and activate PRs, while at a higher dose P4 is inhibitory and may inhibit PRs or cause their rapid downregulation/degradation. This phenomenon is true for all steroid hormone receptors and was the reason for the early use of high-dose DES or testosterone to treat breast or prostate cancer respectively, prior to the routine use of the appropriate anti-hormones for these cancers. It is thus difficult to interpret studies that exceed the range of $1 \mathrm{nM} \mathrm{E} 2$ and 1-10 nM P4 (or R5020).

\section{Hormone Replacement Therapy}

An important fact that needs to be considered is that testosterone levels can vary among women. There is data to suggest that there is a difference in the androgenic hormone levels between premenopausal and postmenopausal women and the impact of $\mathrm{P} 4$ is influenced by the hormonal milieu.

The French E3N cohort study demonstrated an unequal risk for breast cancer associated with different postmenopausal hormonal therapy (49); there was an increased incidence seen in women undergoing hormone replacement therapy (HRT) that contained any synthetic progestin, but not natural P4. A caveat to this study was that increased duration of exposure to $\mathrm{E} 2$ + natural $\mathrm{P} 4$ also showed a trend towards increased BC incidence (49). A limitation of the study as stated by the investigators themselves was that the study was statistically underpowered.

There is no strong epidemiological data showing association between hormone (P4) exposure and breast cancer outcomes. However, $\mathrm{P} 4$ has a protective role for ovarian and endometrial cancers. Conversely, local hormone delivery (Mirena IUD) to fallopian tube results in increased proliferation of ovarian epithelial cells, similar to the situation in an ovulating woman, indicating that they may still have an increased risk of ovarian cancer (comments of Malcolm Pike). Both $\mathrm{E}$ and $\mathrm{P} 4$ are greatly elevated in BRCA mutation carriers, especially $\mathrm{P} 4$, due to a defect in hormone biosynthesis within the ovaries of germline BRCA mutation carriers (50). This is true in humans and has been recapitulated in BRCA-mutant mouse models (51).

\section{Progesterone Levels}

Epidemiological data in postmenopausal women have indicated that P4 levels are low in post-menopausal women. However, this is based on data collected from a small sample size and there have been questions raised regarding the accuracy of the antiquated assays that were used. The role of circulating hormone levels relative to local or intratumoral (i.e., autocrine) hormone levels in disease progression remains controversial (i.e., few studies have measured P4). However, one needs to acknowledge that the predominant source of circulating $\mathrm{P} 4$ in non-pregnant women is cyclical production by the corpus luteum, no longer active after menopause. Although it may be that the production of $\mathrm{P} 4$ by the postmenopausal adrenal gland has been underestimated. In addition, while either E2 or P4 alone are proliferative, the fluctuating high levels of P4 (as ovulation ceases and estrogen levels drop) during perimenopause have the potential to drive the proliferation of existing lesions in the breast (comments of $\mathrm{J}$ Dinny Graham). 


\section{PR and Immune System}

Dr. Christy Hagan's lab (University of Kansas Medical Center, KS) showed that PR promotes an immunosuppressive environment through downregulation of interferon signaling. PR and STAT1 interact; PR-mediated inhibition of interferon signaling may provide a mechanism for $\mathrm{ER}+\mathrm{PR}+$ tumors to escape from immune surveillance (52). Further analysis demonstrated that interferon gene sets are downregulated by PR via the activation of STAT1. PR+ breast tumors show decreased expression of interferon-stimulated genes. R5020 attenuates phosphorylated STAT1 (pSTAT1) levels, suggesting that PR downregulates inputs to pSTAT1. The interaction between PR and STAT1 was robust, but not isoform-specific.

\section{Antibodies}

Christine Clarke's group (University of Sydney) has characterized PR-A and PR-B directed antibodies in human tissue and confirmed their isoform-specific detection using cell lines that express either PR-A or PR-B alone (15). However, other groups (Dean Edwards, Carol Sartorius) have been unable to consistently reproduce these findings, and this may be explained by differences in IHC staining protocol, tissue fixation, and even isolation/age of patient tumor samples. There is also some frustration that some of the existing antibodies do not work ideally for a wide variety of assays (comments of Carol Sartorius). The detection of PR isoforms in tissues remains a challenging and controversial area of study.

\section{Innovative Technology}

Recent advances in technology offer new opportunities to define the molecular status of steroid receptor complexes, particularly DNA bound forms and the potential to impact the clinical translation of these findings. Dr. Gordon Hager and colleagues (National Institutes of Health, MD) employ a technique known as the number and brightness $(\mathrm{N} \& \mathrm{~B})$ method that allows the quantification of the oligomeric state of proteins in living cells (53). N\&B provides a read-out of the size of the molecule that moves through the focus of the microscope. These experiments show that PRs, glucocorticoid receptor (GR), and androgen receptor all adopt multimeric structures when examined in living cells (54). Findings with GR are particularly interesting. GR transitions from a dimeric state to a tetrameric state upon binding to glucocorticoid response elements. Using a mutation that mimics the DNA bound state, it was subsequently shown that the tetrameric state confers on the receptor the ability to access or "pioneer" into closed chromatin, thus activating response elements not available to the dimeric receptor (55). In aggregate, these results open a new chapter in the biology of steroid receptors, raising serious questions concerning the standard homo- or heterodimeric receptor model that has prevailed for more than 30 years.

Dr. Teresa Woodruff (Northwestern University, IL) and her collaborators have innovated the use of a tissue chip in vitro model, called the EVATAR, which uses 3D reproductive tissues and a microfluidic system to recapitulate hormonal changes during the human menstrual cycle over 28 days (56). Tissues from the ovary, fallopian tube, uterus, cervix, and liver were connected in a microfluidic system allowing for the dynamic sharing of media and paracrine factors. The pituitary influence was achieved by manual addition of follicle stimulating hormone and luteinizing hormone receptor ligand. The microfluidics system promoted viability of the $3 \mathrm{D}$ tissuemimics in culture, as fresh nutrients flowed in and waste products were eliminated. Microfluidics also allowed for sharing of paracrine factors between tissues that preserved the biology of each tissue in a systematic fashion. EVATAR was originally designed to test drugs to aid in predicting success in clinical trials but can also be used for research purposes when studying endocrine mechanisms of action of hormones and compounds in multi-organ systems that require long-term treatment times (comments of Julie Kim).

\section{New Models to Study Progesterone Action in Ductal Carcinoma In Situ}

Dr. Dean Edwards presented a ductal carcinoma in situ (DCIS) model using MCF10 DCIS.COM cells engineered with lentiviral vectors to stably express ERalpha, PR-A, and PR-B. Based on gene expression profiling, these cells resemble luminal breast cancer subtypes and are robustly responsive in cell culture to either estrogen or progesterone in terms of regulation of known target genes (57). The cells have also been used successfully in the mouse mammary intraductal xenograft (MIND) system and are responsive to estrogen and progesterone in vivo. In the MIND system, these cells form pure DCIS lesions with histopathological characteristics similar to human disease and eventually undergo breakdown of myoepithelium and basement membrane and invade into stroma. Combined E2 and P4 treatment stimulated upregulation of a NEMO/NF-KB/IL-6 pro-inflammatory pathway in these cells as xenografts in the MIND system. Furthermore, this pathway maintained expression of the PML tumor suppressor, implicating NEMO as a potential tumor suppressor regulated by E2 and $\mathrm{P} 4$ in the transition of DCIS to invasive cancer (58). These ER/PR+ DCIS.COM cell lines appear to be a physiologically relevant model to study molecular mechanisms and the role of progesterone in the transition of DCIS to invasive breast cancer which is largely unknown (59). 


\section{Endometrial Cancer}

PR is protective of E2-induced endometrial hyperplasia and cancer. Thus, another important area of research is the response of endometrial hyperplasia and cancer to $\mathrm{P} 4$ or progestin therapy (comments of Sanaz Memarzadeh). In the case of PTEN null endometrial tumors, wherein PTEN was only lost in the endometrial epithelia, the tumors were hormonesensitive and had abundant expression of stromal PR. Stromal deletion of PR as a single genetic change in these tumors induced $\mathrm{P} 4$ resistance indicating that paracrine signaling through the stroma was essential for the P4-induced therapeutic effects (60). Work by many investigators has shown that levonorgestrel (LVG) can be an appropriate therapy for localized endometrial hyperplasia and tumors (60). However, patients presenting with metastatic disease are not good candidates for treatment with an IUD and systemic therapy with P4 can be considered. A clinical challenge is that reliable predictors of response to $\mathrm{P} 4$ therapy are not readily available and need to be explored more extensively. The expression of PR in the stroma may serve as a discriminatory biomarker of P4 sensitivity in endometrial hyperplasia based on analysis of a small cohort of patients (60) but needs to be validated in a larger cohort.

\section{Discussion}

Below are additional discussion points from workshop attendees that have been captured verbatim or revised by the speaker contributors herein.

\section{Epidemiology}

There is speculation about the mechanism of action of MPA in the Women's Health Initiative and Million Women's studies. Is the effect of MPA in altering ER signaling accomplished via its agonistic effect on AR in normal breast tissue to increase breast cancer risk? This is an area that requires further examination. While the Women's Health Initiative and Million Women Study found a significantly increased risk with MPA and other synthetic progestins (61-63), two studies in France and Finland reported no association between use of the natural hormone $\mathrm{P} 4$ and breast cancer risk $(29,49)$. It appears that the type of progestin, dose, and patient age seem to all affect the risk and we do not know enough yet.

The postmenopausal estrogen/progestin intervention (PEPI) study shows that P4 at $200 \mathrm{mg}$ per day did increase density although not as much as MPA (64). However, use of a $200 \mathrm{mg}$ dose of P4 may not prevent endometrial cancers, while $200 \mathrm{mg}$ was effective in decreasing endometrial proliferation $(65,66)$, the studies that use "micronized" $\mathrm{P} 4$ reported that it was not protective. The "micronized" form needs to be absorbed/has low bioavailability relative to other forms (i.e., of PR agonists) which is a whole different story (i.e., a further complication with regard to sources of variability and data interpretation (67)).

Estrogen replacement therapy is very similar to estrogen plus P4 therapy - this is because the P4 dose is too low; the low dose was chosen as it prevents endometrial hyperplasia. However, endometrial hyperplasia is not a good model. This tissue can exhibit high levels of cell proliferation without hyperplasia; we also have strong evidence of no hyperplasia in E2-treated premenopausal woman. Most PR researchers like the idea of using P4 (i.e., progesterone). Related to this topic, a recent meta-analysis of the worldwide epidemiological evidence reports findings of an increased breast cancer risk in women taking menopausal hormone therapy (i.e., as E2 alone, E2 with daily P4, or E2 with intermittent P4); risk increased with each preparation, but varied by type of preparation and duration of use (33).

\section{PR Antibodies}

Dr. Greene's group has successfully used the commercially available KD68 antibody for ChIP analyses. Santa Cruz replacement antibody (F4) was also used successfully in Lange lab for ChIP, but this antibody favors PR-A isoform over PRB. There was consensus that there should be greater attention paid to validating the antibodies and publishing details regarding the protocols used so that it is reproducible in different laboratories.

Dr. Khokha indicated that they had issues when they tried the commercially available RANK antibody. In addition, RANKL mRNA is difficult to measure.

Dr. Sartorius: We have used Thermo AB-8 and other of the Graham/Clarke antibodies for ChIP with success. There are production and consistency problems with the Thermo antibodies, so it has been challenging.

\section{Hormone Replacement Therapy}

Dr. Lange: The progesterone or progestin effect is influenced by the model being used. While in one ER+/PR+ model (BT474 cells) onapristone is very effective, mifepristone (RU486) does little to nothing. This can be flipped in another model such as MCF-7 or T47D cells and is also dependent on the assay type or culture system (i.e. using $2 \mathrm{D}$ vs. $3 \mathrm{D}$ conditions) (CA Lange lab, unpublished data). Relevant to this discussion, ER and PR-B (but not PR-A) directly interact in co-IP or ChIP assays and E2 stimulates a number of genes only in PR-B+ (but 
not PR-null or PR-A+) cells (3). We have observed that phosphorylation of PR Ser294 is important for the ER/ PR-B interaction (TH Truong and CA Lange, unpublished data). Thus, selected antiprogestin agents (such as onapristone or PRA-027) that block Ser294 phosphorylation may inhibit this interaction while others (RU486) may actually stimulate ER/PR binding. We also see stronger effects with agents (onapristone) in cell lines with high ER expression relative to cell lines with lower ER levels, suggesting that this agent/agents in this class are working in part via altering/disrupting PR cross talk with ER rather than by strictly inhibiting PR.

Dr. Rui: Going back to HRT data and the impact of chronic progestin, it is believed that the stem cells that express PR, and are believed to be the tumor initiating cells, are the target. However, it appears that progestins have an impact in only some women. Is it because the cells are heterogenous?

Dr. Graham: That is the implication. We need to understand what the transcriptional data are telling us because PR is expressed in basal cells, but the expression is lower than in luminal cells. I think the expression of PR is real, is not an artifact. The staining is clean. The other evidence we have is the $\mathrm{P} 4$ effect on cellular proliferation.

Dr. Khokha: We have seen positivity in basal cells and it is very real.

\section{Effect of Progesterone on Stem Cells}

Most of the data so far suggest CSCs are ER and PR negative - or become that way once exposed to hormones. There are also differences in mice vs. humans (in humans, it appears that some basal progenitor cells are $\mathrm{PR}+$ ). We also have to be careful distinguishing normal from CSCs.

Dr. Rui: I have a question for you Dinny. You used the terminology - "progesterone pushing cells into the stem cell phenotype". I wasn't clear if it was proliferative expansion or reprogramming?

Dr. Graham: We do not know yet. The treatment was done for 14 hours only; hence it is hard to believe it is the result of proliferation and suggests that the increase must at least in part reflect reprogramming, since what we are seeing is an increase in the proportion of cells expressing a stem/progenitor gene signature. If we extend the time we would see more. We need to do more work to understand why that is happening.
Dr. Rui: CK5-positive cancer cells have 'progenitor-like' features, for progesterone to stimulate their expansion, we imagine that is more reprogramming than proliferative expansion. Do you have a comment on that, Carol?

Dr. Sartorius: It's hard to measure. The closest we got is we seeded single cells labeled with a CK5 promoterGFP reporter then added progesterone. Some cells turned green when alone, but one could argue that in those cells an autocrine feedback loop was initiated, but we cannot know for sure unless we are able to immunostain the single cell for CK5 - it is difficult to go back and stain a single cell for that.

Dr. Graham: Our primary embedded 3D model of normal breast tends to support progenitors, because the culture model supports the growth and formation of new structures, and when we stain the structures there is a high level of CK5 positivity. This can mean that measuring CK5 in the model is not very informative. However, my main point was that we tend to see quite a high proportion of CK5 positivity in our model, which likely reflects the fact that the structures formed actively proliferate, unlike the majority of other primary normal breast in vitro models, where it is very difficult to see a proliferation effect because the samples do not actually proliferate. Our model supports proliferation of these structures, we have higher than normal proliferative components, CK5 expression is seen in a lot of cells in the culture, which is different than resting tissue. The size of the progenitor population is also greater than you would expect to see in a tissue sample that has not been in culture. We did not see progesterone upregulating CK5 in any of our clusters but would have to go back and look. I have checked in our data and confirm we do not see up regulation of CK5 in progenitor populations by $\mathrm{P}$. However, we do see down regulation in the mature luminal population.

Dr. Khokha: What was striking from our global mammary cell profiling data (68), and we do not know what it means, but ATAC-seq and methylome data on primary cells shows that PR in basal compartment sits in 'open chromatin' region. This dataset is quite interesting, I wonder if people who are experts could examine it. Another piece of data looked at lineage- specific markers generated as a module. We look at module for methylation pattern, transcription, proteomes, and you see interesting shifts that occur in individual markers after progesterone stimulation.

When treated with P4, while it may be true that breast tumor cell proliferation is inhibited, the fact is that there is an increase in the stem cell population in these tumors, which can be dangerous. 
Dr. Sartorius: There is an expansion of stem cells with every cycle - so is there a cumulative increase in the number of stem cells over a woman's life? If we could measure the number of bona fide stem cells over age, one might predict it would cumulatively increase.

Dr. Khokha: There is not an easy way to answer that, because those kinds of experiments are not easy to do. The cells turnover, but what we did do is we looked at it in wild type mice in relation to age. In relation to other models, we have calculated in wild type mice the ones that have aged for 18 months and have tried to see how the different cell fractions changed. There is not a lot of net increase in total number of cells. It seems like they are expanding and then reverting to baseline.

\section{Consensus on Experimental Conditions for the Study of PR Actions}

Several researchers emphasized that under physiologically relevant conditions, a woman is never exposed to progesterone alone. Even in postmenopausal women, there are always endogenous estrogens present. Hence, any experiment that involves studying progesterone must be done in the presence of estrogen.

Dr. Sartorius: There was nothing happening in the breast cells, so after that we got rid of progesterone alone. We just use estrogen or progesterone and estrogen. That is why it is troubling to see titles talking about cancers being affected by estrogen alone and not progesterone. Dinny Graham's work supported this, showing that unopposed E2 stimulates proliferation but when P4 is also present the proliferative influence decreased. This is consistent with the cyclical pattern of proliferation in the normal breast through the menstrual cycle.

Dr. Lange: A reviewer at minimum should have asked to see the level of PR in that model. In a mouse model, did those mice have decent PR expression in the tissue to make that conclusion? At least for cells, we show the Western blots for both ER and PR. We used to call it priming, you prime with Estrogen then you get PR activity. It is a confounding thing to put all the hormones together. You have to do everything (i.e. each alone and then together). In addition, I would stress that if one is studying ligandindependent actions of either ER or PR, obviously the studies are completed in the absence of added hormones as an experimental variable, and compared to plus hormones (thus the study designs that exclude added hormones are relevant to trying to understand how growth factors may activate or otherwise regulate steroid hormone receptors in little to no ligand, for example and controlled by showing the plus hormone condition).

Dr. Sartorius: When doing in vitro experiments, each of these conditions can be measured. One can add estrogen, progesterone, and combination. In vivo experiments almost always need estrogen. However, we then get criticized if we do not have a progesterone alone group, despite that most tumors do not then grow. It is confounding.

Dr. Lange: Those not familiar with the field ask why a Progesterone alone study was not done. The confusing area for me is that I do not think we really reached any consensus on adding estrogen to experiments on PRs or not - I think we do need to include all conditions so we can interpret the data and see what happens in each condition - but because at least in my hands and also Claudia Lanari's FGF2 work - we are seeing much ligand-independent ER and PR actions that are phosphorylation dependent - in which ER can act as a binding partner scaffold of liganded PR (Myc expression), and vice versa - PR and act as a scaffold for ligand-bound ER (CTSD gene) - we and the Lanari group see both ways - some genes respond to only one ligand - others need both - some only need a growth factor (EGF or FGF from stroma)- I think hormone-ablated women model the no/low hormone and high signaling or growth factor state so these experimental conditions are relevant to that - it is remarkable to me to see what these receptors can do without exogenous hormone - amazing really - they want to be on - and growth factors can sub during cancer contexts - at least growth factors very much lower the concentration of ligand needed to activate PR (i.e. 4-5 orders of magnitude lower when some EGF is around).

\section{Critical Questions That Need to Be Addressed in the PR Field}

Can the effects of a progesterone antagonist be reversed with an agonist?

Dr. Graham: Several mechanistic studies from the 1980s and 1990s have demonstrated that the ability to overcome antagonism was dependent on the strength of the binding affinity and relative dose. I think it's clear that antagonism can be overcome if there is the right context. For antagonists to really oppose strong synthetic agonists, they have to be present at 100-fold higher concentration than the agonist. So, I think the answer is yes, depending on antagonist dose, agonist can oppose its effects, but whether they will completely reverse the antagonism is concentration- 
dependent, since at very high dose agonists will behave more like antagonist themselves.

\section{Tools That the PR Research Community Needs for Progress}

The scientific community engaged in $\mathrm{P} / \mathrm{PR}$ research does not have the tools they need. There are good synthetic progesterone receptor agonists and antagonists but at present they are not easily available to everyone. Dr. McDonnell (Duke University, NC) offered that they would be willing to make these reagents for researchers. However, he stressed the need for a group that would work on validating the progestins.

Reagents/cell lines needed: There are very few cell line models to study invasive lobular cancer (ILC). Of the seven that are available, three are ER+ and two are ER+/PR+. There is a need for further studies to understand why P4/PR effects on proliferation in vivo are different in ILC and IDC. PR isoforms should also be considered in ILC. There is a need for more PR+ cell lines since MCF7 cells make very little PR even in the presence of estrogen.

\section{Workshop Participants}

Cathrin Brisken, MD PhD (Ecole Polytechnique Federale, Switzerland)

Amy R. Dwyer, PhD (University of Minnesota)

Dean Edwards, PhD (Baylor College of Medicine)

Dan Gallahan, PhD (NCI, Division of Cancer Biology)

Geoffrey Greene, $\mathrm{PhD}$ (University of Chicago)

J. Dinny Graham, PhD (Westmead Institute for Medical Research, Australia)

Christy Hagan, PhD (University of Kansas Medical Center)

Gordon Hager, $\mathrm{PhD}$ (NCI, Center for Cancer Research)

Brandy Heckman-Stoddard, PhD MPH (NCI, Division of Cancer Prevention)

Jeffrey Hildesheim PhD (NCI, Division of Cancer Biology)

Britta M. Jacobsen, PhD (University of Colorado Anschutz Medical Campus)

Seema Khan, MD (Northwestern University)

Rama Khokha, $\mathrm{PhD}$ (University of Toronto)

J. Julie Kim, PhD (Northwestern University)

Carol A. Lange, $\mathrm{PhD}$ (University of Minnesota)

Oukseub Lee, $\mathrm{PhD}$ (Northwestern University)

Donald McDonnell, PhD (Duke University School of Medicine)

Sanaz Memarzadeh, MD PhD (ULCA Medical Center Santa Monica)

Jason Northey, PhD (University of California-San Francisco)
Malcolm Pike, PhD (Memorial Sloan Kettering Cancer Center)

Hallgeir Rui, MD PhD (Medical College of Wisconsin)

Carol Sartorius, PhD (University of Colorado Denver)

Neeraja Sathyamoorthy, PhD (NCI, Division of Cancer

Biology)

Mark Sherman, MD (Mayo Clinic)

Thu H. Truong, PhD (University of Minnesota)

Carolyn Westhoff MD (Columbia University Medical Center)

\section{References}

1. Giangrande PH, Kimbrel EA, Edwards DP, McDonnell DP. The opposing transcriptional activities of the two isoforms of the human progesterone receptor are due to differential cofactor binding. Mol Cell Biol. 2000;20(9):3102-15. doi: https://doi.org/10.1128/mcb. 20.9.3102-3115.2000. PubMed PMID: 10757795; PMCID: PMC85605

2. Singhal H, Greene ME, Zarnke AL, Laine M, Al Abosy R, Chang YF, Dembo AG, Schoenfelt K, Vadhi R, Qiu X, Rao P, Santhamma B, Nair HB, Nickisch KJ, Long HW, Becker L, Brown M, Greene GL. Progesterone receptor isoforms, agonists and antagonists differentially reprogram estrogen signaling. Oncotarget. 2018;9(4): 4282-300. doi: https://doi.org/10.18632/oncotarget.21378. PubMed PMID: 29435103; PMCID: PMC5796974

3. Daniel AR, Gaviglio AL, Knutson TP, Ostrander JH, D'Assoro AB, Ravindranathan P, Peng Y, Raj GV, Yee D, Lange CA. Progesterone receptor-B enhances estrogen responsiveness of breast cancer cells via scaffolding PELP1- and estrogen receptor-containing transcription complexes. Oncogene. 2015;34(4):506-15. doi: https://doi. org/10.1038/onc.2013.579. PubMed PMID: 24469035; PMCID: PMC4112172

4. Migliaccio A, Piccolo D, Castoria G, Di Domenico M, Bilancio A, Lombardi M, Gong W, Beato M, Auricchio F. Activation of the Src/ p21 ras/Erk pathway by progesterone receptor via cross-talk with estrogen receptor. EMBO J. 1998;17(7):2008-18. doi: https://doi. org/10.1093/emboj/17.7.2008. PubMed PMID: 9524123; PMCID: PMC1170546

5. Mohammed H, Russell IA, Stark R, Rueda OM, Hickey TE, Tarulli GA, Serandour AA, Birrell SN, Bruna A, Saadi A, Menon S, Hadfield J, Pugh M, Raj GV, Brown GD, D'Santos C, Robinson JL, Silva G, Launchbury R, Perou CM, Stingl J, Caldas C, Tilley WD, Carroll JS. Progesterone receptor modulates ERalpha action in breast cancer. Nature. 2015;523(7560):313-7. doi: https://doi.org/ 10.1038/nature14583. PubMed PMID: 26153859; PMCID: PMC4650274

6. Truong TH, Dwyer AR, Diep CH, Hu H, Hagen KM, Lange CA. Phosphorylated progesterone receptor isoforms mediate opposing stem cell and proliferative breast cancer cell fates. Endocrinology. 2019;160(2):430-46. doi: https://doi.org/10.1210/en.2018-00990. PubMed PMID: 30597041; PMCID: PMC6349004

7. Graham JD, Yeates C, Balleine RL, Harvey SS, Milliken JS, Bilous AM, Clarke CL (1995) Characterization of progesterone receptor A and B expression in human breast cancer. Cancer Res 55(21):50635068

8. Bamberger AM, Milde-Langosch K, Schulte HM, Loning T (2000) Progesterone receptor isoforms, PR-B and PR-A, in breast cancer: correlations with clinicopathologic tumor parameters and 
expression of AP-1 factors. Horm Res 54(1):32-37. https://doi.org/ $10.1159 / 000063434$

9. Hopp TA, Weiss HL, Hilsenbeck SG, Cui Y, Allred DC, Horwitz KB, Fuqua SA (2004) Breast cancer patients with progesterone receptor PR-A-rich tumors have poorer disease-free survival rates. Clin Cancer Res 10(8):2751-2760. https://doi.org/10.1158/10780432.ccr-03-0141

10. Mote PA, Gompel A, Howe C, Hilton HN, Sestak I, Cuzick J, Dowsett M, Hugol D, Forgez P, Byth K, Graham JD, Clarke CL (2015) Progesterone receptor A predominance is a discriminator of benefit from endocrine therapy in the ATAC trial. Breast Cancer Res Treat 151(2):309-318. https://doi.org/10.1007/s10549-0153397-0

11. Rojas PA, May M, Sequeira GR, Elia A, Alvarez M, Martinez P, Gonzalez P, Hewitt S, He X, Perou CM, Molinolo A, Gibbons L, Abba MC, Gass H, Lanari C. Progesterone receptor isoform ratio: a breast cancer prognostic and predictive factor for antiprogestin responsiveness. J Natl Cancer Inst. 2017;109(7). doi: https://doi.org/ 10.1093/jnci/djw317

12. Daniel AR, Faivre EJ, Lange CA (2007) Phosphorylationdependent antagonism of sumoylation derepresses progesterone receptor action in breast cancer cells. Mol Endocrinol 21(12): 2890-2906. https://doi.org/10.1210/me.2007-0248

13. Bonneterre J, Bosq J, Jamme P, Valent A, Gilles EM, Zukiwski AA, Fuqua SA, Lange CA, O'Shaughnessy J. Tumour and cellular distribution of activated forms of PR in breast cancers: a novel immunohistochemical analysis of a large clinical cohort. ESMO Open. 2016;1(4):e000072. doi: https://doi.org/10.1136/esmoopen-2016000072. PubMed PMID: 27843626; PMCID: PMC5070234

14. Mote PA, Bartow S, Tran N, Clarke CL (2002) Loss of co-ordinate expression of progesterone receptors $\mathrm{A}$ and $\mathrm{B}$ is an early event in breast carcinogenesis. Breast Cancer Res Treat 72(2):163-172. Epub 2002/06/01. https://doi.org/10.1023/a:1014820500738

15. Mote PA, Johnston JF, Manninen T, Tuohimaa P, Clarke CL. Detection of progesterone receptor forms A and B by immunohistochemical analysis. J Clin Pathol. 2001;54(8):624-30. doi: https:// doi.org/10.1136/jcp.54.8.624. PubMed PMID: 11477119; PMCID: PMC1731503

16. Fabris V, Abascal MF, Giulianelli S, May M, Sequeira GR, Jacobsen B, Lombes M, Han J, Tran L, Molinolo A, Lanari C (2017) Isoform specificity of progesterone receptor antibodies. J Pathol Clin Res 3(4):227-233. https://doi.org/10.1002/cjp2.83

17. De Vivo I, Huggins GS, Hankinson SE, Lescault PJ, Boezen M, Colditz GA, Hunter DJ (2002) A functional polymorphism in the promoter of the progesterone receptor gene associated with endometrial cancer risk. Proc Natl Acad Sci U S A 99(19):1226312268. https://doi.org/10.1073/pnas.192172299

18. Junqueira MG, da Silva ID, Nogueira-de-Souza NC, Carvalho CV, Leite DB, Gomes MT, Baracat EC, Lopes LA, Nicolau SM, Goncalves WJ (2007) Progesterone receptor (PROGINS) polymorphism and the risk of endometrial cancer development. Int $\mathrm{J}$ Gynecol Cancer 17(1):229-232. https://doi.org/10.1111/j.15251438.2006.00767.x

19. Liu T, Chen L, Sun X, Wang Y, Li S, Yin X, Wang X, Ding C, Li H, Di W (2014) Progesterone receptor PROGINS and +331G/A polymorphisms confer susceptibility to ovarian cancer: a meta-analysis based on 17 studies. Tumour Biol 35(3):2427-2436. https://doi.org/ 10.1007/s13277-013-1322-x

20. Govindan S, Ahmad SN, Vedicherla B, Kodati V, Jahan P, Rao KP, Ahuja YR, Hasan Q (2007) Association of progesterone receptor gene polymorphism (PROGINS) with endometriosis, uterine fibroids and breast cancer. Cancer Biomark 3(2):73-78. https://doi. org/10.3233/cbm-2007-3201

21. Owen GI, Richer JK, Tung L, Takimoto G, Horwitz KB (1998) Progesterone regulates transcription of the $\mathrm{p} 21$ (WAF1) cyclin- dependent kinase inhibitor gene through Sp1 and CBP/p300. J Biol
Chem 273(17):10696-10701. https://doi.org/10.1074/jbc.273.17. 10696

22. Agoulnik IU, Tong XW, Fischer DC, Korner K, Atkinson NE, Edwards DP, Headon DR, Weigel NL, Kieback DG (2004) A germline variation in the progesterone receptor gene increases transcriptional activity and may modify ovarian cancer risk. J Clin Endocrinol Metab 89(12):6340-6347. https://doi.org/10.1210/jc. 2004-0114

23. Lamb CA, Fabris VT, Jacobsen B, Molinolo AA, Lanari C (2018) Biological and clinical impact of imbalanced progesterone receptor isoform ratios in breast cancer. Endocr Relat Cancer. https://doi.org/ 10.1530/ERC-18-0179

24. Pathiraja TN, Shetty PB, Jelinek J, He R, Hartmaier R, Margossian AL, Hilsenbeck SG, Issa JP, Oesterreich S (2011) Progesterone receptor isoform-specific promoter methylation: association of PRA promoter methylation with worse outcome in breast cancer patients. Clin Cancer Res 17(12):4177-4186. https://doi.org/10. 1158/1078-0432.CCR-10-2950

25. Spicer DV, Ursin G, Parisky YR, Pearce JG, Shoupe D, Pike A, Pike MC (1994) Changes in mammographic densities induced by a hormonal contraceptive designed to reduce breast cancer risk. J Natl Cancer Inst 86(6):431-436. https://doi.org/10.1093/jnci/86.6.431

26. Thomas CP, Liu KZ, Vats HS (2006) Medroxyprogesterone acetate binds the glucocorticoid receptor to stimulate alpha-ENaC and sgk1 expression in renal collecting duct epithelia. Am J Physiol Renal Physiol 290(2):F306-F312. https://doi.org/10.1152/ajprenal. 00062.2005

27. Bentel JM, Birrell SN, Pickering MA, Holds DJ, Horsfall DJ, Tilley WD (1999) Androgen receptor agonist activity of the synthetic progestin, medroxyprogesterone acetate, in human breast cancer cells. Mol Cell Endocrinol 154(1-2):11-20. https://doi.org/10. 1016/s0303-7207(99)00109-4

28. Bray JD, Jelinsky S, Ghatge R, Bray JA, Tunkey C, Saraf K, Jacobsen BM, Richer JK, Brown EL, Winneker RC, Horwitz KB, Lyttle CR (2005) Quantitative analysis of gene regulation by seven clinically relevant progestins suggests a highly similar mechanism of action through progesterone receptors in T47D breast cancer cells. J Steroid Biochem Mol Biol 97(4):328-341. https://doi.org/ 10.1016/j.jsbmb.2005.06.032

29. Soini T, Hurskainen R, Grenman S, Maenpaa J, Paavonen J, Pukkala E (2014) Cancer risk in women using the levonorgestrelreleasing intrauterine system in Finland. Obstet Gynecol 124(2 Pt 1):292-299. https://doi.org/10.1097/AOG.0000000000000356

30. Morch LS, Skovlund CW, Hannaford PC, Iversen L, Fielding S, Lidegaard O (2017) Contemporary hormonal contraception and the risk of breast cancer. N Engl J Med 377(23):2228-2239. https://doi. org/10.1056/NEJMoa1700732

31. Africander DJ, Storbeck KH, Hapgood JP (2014) A comparative study of the androgenic properties of progesterone and the progestins, medroxyprogesterone acetate (MPA) and norethisterone acetate (NET-A). J Steroid Biochem Mol Biol 143:404-415. https:// doi.org/10.1016/j.jsbmb.2014.05.007

32. Louw-du Toit R, Perkins MS, Hapgood JP, Africander D (2017) Comparing the androgenic and estrogenic properties of progestins used in contraception and hormone therapy. Biochem Biophys Res Commun 491(1):140-146. https://doi.org/10.1016/j.bbrc.2017.07. 063

33. Collaborative Group on Hormonal Factors in Breast C (2019) Type and timing of menopausal hormone therapy and breast cancer risk: individual participant meta-analysis of the worldwide epidemiological evidence. Lancet. 394(10204):1159-1168. https://doi.org/10. 1016/S0140-6736(19)31709-X

34. Ciriello G, Gatza ML, Beck AH, Wilkerson MD, Rhie SK, Pastore A, Zhang H, McLellan M, Yau C, Kandoth C, Bowlby R, Shen H, Hayat S, Fieldhouse R, Lester SC, Tse GM, Factor RE, Collins LC, Allison KH, Chen YY, Jensen K, Johnson NB, Oesterreich S, Mills 
GB, Cherniack AD, Robertson G, Benz C, Sander C, Laird PW, Hoadley KA, King TA, Network TR, Perou CM (2015) Comprehensive molecular portraits of invasive lobular breast cancer. Cell. 163(2):506-519. https://doi.org/10.1016/j.cell.2015.09. 033

35. Tasdemir N, Bossart EA, Li Z, Zhu L, Sikora MJ, Levine KM, Jacobsen BM, Tseng GC, Davidson NE, Oesterreich S (2018) Comprehensive phenotypic characterization of human invasive lobular carcinoma cell lines in 2D and 3D cultures. Cancer Res 78(21): 6209-6222. https://doi.org/10.1158/0008-5472.CAN-18-1416

36. Michaut M, Chin SF, Majewski I, Severson TM, Bismeijer T, de Koning L, Peeters JK, Schouten PC, Rueda OM, Bosma AJ, Tarrant F, Fan Y, He B, Xue Z, Mittempergher L, Kluin RJ, Heijmans J, Snel M, Pereira B, Schlicker A, Provenzano E, Ali HR, Gaber A, O'Hurley G, Lehn S, Muris JJ, Wesseling J, Kay E, Sammut SJ, Bardwell HA, Barbet AS, Bard F, Lecerf C, O'Connor DP, Vis DJ, Benes CH, McDermott U, Garnett MJ, Simon IM, Jirstrom K, Dubois T, Linn SC, Gallagher WM, Wessels LF, Caldas C, Bernards R. Integration of genomic, transcriptomic and proteomic data identifies two biologically distinct subtypes of invasive lobular breast cancer. Sci Rep. 2016;6:18517. doi: https://doi.org/10.1038/ srep 18517

37. Dossus L, Benusiglio PR (2015) Lobular breast cancer: incidence and genetic and non-genetic risk factors. Breast Cancer Res 17:37. https://doi.org/10.1186/s13058-015-0546-7

38. Harrell JC, Shroka TM, Jacobsen BM (2017) Estrogen induces c-kit and an aggressive phenotype in a model of invasive lobular breast cancer. Oncogenesis. 6(11):396. https://doi.org/10.1038/s41389017-0002-x

39. Matthews SB, Sartorius CA (2017) Steroid hormone receptor positive breast cancer patient-derived xenografts. Horm Cancer 8(1):4 15. https://doi.org/10.1007/s12672-016-0275-0

40. Dobrolecki LE, Airhart SD, Alferez DG, Aparicio S, Behbod F, Bentires-Alj M, Brisken C, Bult CJ, Cai S, Clarke RB, Dowst H, Ellis MJ, Gonzalez-Suarez E, Iggo RD, Kabos P, Li S, Lindeman GJ, Marangoni E, McCoy A, Meric-Bernstam F, Piwnica-Worms H, Poupon MF, Reis-Filho J, Sartorius CA, Scabia V, Sflomos G, $\mathrm{Tu}$ Y, Vaillant F, Visvader JE, Welm A, Wicha MS, Lewis MT. Patient-derived xenograft (PDX) models in basic and translational breast cancer research. Cancer Metastasis Rev. 2016;35(4):547-73. doi: https://doi.org/10.1007/s10555-016-9653-x

41. Finlay-Schultz J, Gillen AE, Brechbuhl HM, Ivie JJ, Matthews SB, Jacobsen BM, Bentley DL, Kabos P, Sartorius CA (2017) Breast cancer suppression by progesterone receptors is mediated by their modulation of estrogen receptors and RNA polymerase III. Cancer Res 77(18):4934-4946. https://doi.org/10.1158/0008-5472.CAN16-3541

42. Sflomos G, Dormoy V, Metsalu T, Jeitziner R, Battista L, Scabia V, Raffoul W, Delaloye JF, Treboux A, Fiche M, Vilo J, Ayyanan A, Brisken C (2016) A preclinical model for ERalpha-positive breast cancer points to the epithelial microenvironment as determinant of luminal phenotype and hormone response. Cancer Cell 29(3):407422. https://doi.org/10.1016/j.ccell.2016.02.002

43. Fiche M, Scabia V, Aouad P, Battista L, Treboux A, Stravodimou A, Zaman K (2019) Rls, Dormoy V, Ayyanan a, Sflomos G, Brisken C. Intraductal patient-derived xenografts of estrogen receptor alpha-positive breast cancer recapitulate the histopathological spectrum and metastatic potential of human lesions. J Pathol 247(3):287-292. https://doi.org/10.1002/path.5200

44. Knutson TP, Lange CA (2014) Tracking progesterone receptormediated actions in breast cancer. Pharmacol Ther 142(1):114 125. https://doi.org/10.1016/j.pharmthera.2013.11.010

45. Tanos T, Sflomos G, Echeverria PC, Ayyanan A, Gutierrez M, Delaloye JF, Raffoul W, Fiche M, Dougall W, Schneider P, Yalcin-Ozuysal O, Brisken C. Progesterone/RANKL is a major regulatory axis in the human breast. Sci Transl Med. 2013;5(182): 182ra55. doi: https://doi.org/10.1126/scitranslmed.3005654

46. Rajaram RD, Buric D, Caikovski M, Ayyanan A, Rougemont J, Shan J, Vainio SJ, Yalcin-Ozuysal O, Brisken C. Progesterone and Wnt4 control mammary stem cells via myoepithelial crosstalk. EMBO J. 2015;34(5):641-52. doi: https://doi.org/10.15252/embj. 201490434

47. Schramek D, Leibbrandt A, Sigl V, Kenner L, Pospisilik JA, Lee HJ, Hanada R, Joshi PA, Aliprantis A, Glimcher L, Pasparakis M, Khokha R, Ormandy CJ, Widschwendter M, Schett G, Penninger JM (2010) Osteoclast differentiation factor RANKL controls development of progestin-driven mammary cancer. Nature. 468(7320): 98-102. https://doi.org/10.1038/nature09387

48. Joshi PA, Jackson HW, Beristain AG, Di Grappa MA, Mote PA, Clarke CL, Stingl J, Waterhouse PD, Khokha R (2010) Progesterone induces adult mammary stem cell expansion. Nature. 465(7299):803-807. https://doi.org/10.1038/nature09091

49. Fournier A, Berrino F, Clavel-Chapelon F (2008) Unequal risks for breast cancer associated with different hormone replacement therapies: results from the E3N cohort study. Breast Cancer Res Treat 107(1):103-111. https://doi.org/10.1007/s10549-007-9523-x

50. Widschwendter M, Rosenthal AN, Philpott S, Rizzuto I, Fraser L, Hayward J, Intermaggio MP, Edlund CK, Ramus SJ, Gayther SA, Dubeau L, Fourkala EO, Zaikin A, Menon U, Jacobs IJ (2013) The sex hormone system in carriers of BRCA1/2 mutations: a casecontrol study. Lancet Oncol 14(12):1226-1232. https://doi.org/10. 1016/S1470-2045(13)70448-0

51. Kim J, Oktay K (2013) Baseline E(2) levels are higher in BRCA2 mutation carriers: a potential target for prevention? Cancer Causes Control 24(3):421-426. https://doi.org/10.1007/s10552-012-01273

52. Goodman ML, Trinca GM, Walter KR, Papachristou EK, D'Santos CS, Li T, Liu Q, Lai Z, Chalise P, Madan R, Fan F, Markiewicz MA, Jin VX, Carroll JS, Hagan CR (2019) Progesterone receptor attenuates STAT1-mediated IFN signaling in breast cancer. J Immunol 202(10):3076-3086. https://doi.org/10.4049/jimmunol.1801152

53. Presman DM, Ogara MF, Stortz M, Alvarez LD, Pooley JR, Schiltz RL, Grontved L, Johnson TA, Mittelstadt PR, Ashwell JD, Ganesan S, Burton G, Levi V, Hager GL, Pecci A (2014) Live cell imaging unveils multiple domain requirements for in vivo dimerization of the glucocorticoid receptor. PLoS Biol 12(3):e1001813. https://doi. org/10.1371/journal.pbio.1001813

54. Presman DM, Ganguly S, Schiltz RL, Johnson TA, Karpova TS, Hager GL (2016) DNA binding triggers tetramerization of the glucocorticoid receptor in live cells. Proc Natl Acad Sci U S A 113(29): 8236-8241. https://doi.org/10.1073/pnas.1606774113

55. Paakinaho V, Johnson TA, Presman DM, Hager GL (2019) Glucocorticoid receptor quaternary structure drives chromatin occupancy and transcriptional outcome. Genome Res 29(8):12231234. https://doi.org/10.1101/gr.244814.118

56. Xiao S, Coppeta JR, Rogers HB, Isenberg BC, Zhu J, Olalekan SA, McKinnon KE, Dokic D, Rashedi AS, Haisenleder DJ, Malpani SS, Arnold-Murray CA, Chen K, Jiang M, Bai L, Nguyen CT, Zhang J, Laronda MM, Hope TJ, Maniar KP, Pavone ME, Avram MJ, Sefton EC, Getsios S, Burdette JE, Kim JJ, Borenstein JT, Woodruff TK (2017) A microfluidic culture model of the human reproductive tract and 28-day menstrual cycle. Nat Commun 8:14584. https:// doi.org/10.1038/ncomms14584

57. Villanueva H, Grimm S, Dhamne S, Rajapakshe K, Visbal A, Davis CM, Ehli EA, Hartig SM, Coarfa C, Edwards DP (2018) The emerging roles of steroid hormone receptors in ductal carcinoma in situ (DCIS) of the breast. J Mammary Gland Biol Neoplasia 23(4):237-248. https://doi.org/10.1007/s10911-018-9416-0

58. Elsarraj HS, Valdez KE, Hong Y, Grimm SL, Ricci LR, Fan F, Tawfik O, May L, Cusick T, Inciardi M, Redick M, Gatewood J, Winblad O, Hilsenbeck S, Edwards DP, Hagan CR, Godwin AK, 
Fabian C, Behbod F (2017) NEMO, a transcriptional target of estrogen and progesterone, is linked to tumor suppressor PML in breast cancer. Cancer Res 77(14):3802-3813. https://doi.org/10. 1158/0008-5472.CAN-16-2794

59. Valdez KE, Fan F, Smith W, Allred DC, Medina D, Behbod F (2011) Human primary ductal carcinoma in situ (DCIS) subtypespecific pathology is preserved in a mouse intraductal (MIND) xenograft model. J Pathol 225(4):565-573. https://doi.org/10. 1002/path.2969

60. Janzen DM, Rosales MA, Paik DY, Lee DS, Smith DA, Witte ON, Iruela-Arispe ML, Memarzadeh S (2013) Progesterone receptor signaling in the microenvironment of endometrial cancer influences its response to hormonal therapy. Cancer Res 73(15):4697-4710. https://doi.org/10.1158/0008-5472.CAN-13-0930

61. Rossouw JE, Anderson GL, Prentice RL, LaCroix AZ, Kooperberg C, Stefanick ML, Jackson RD, Beresford SA, Howard BV, Johnson KC, Kotchen JM, Ockene J, Writing Group for the Women's Health Initiative I. Risks and benefits of estrogen plus progestin in healthy postmenopausal women: principal results from the Women's Health Initiative randomized controlled trial. JAMA. 2002;288(3):321333. doi: https://doi.org/10.1001/jama.288.3.321

62. Chlebowski RT, Anderson GL, Gass M, Lane DS, Aragaki AK, Kuller LH, Manson JE, Stefanick ML, Ockene J, Sarto GE, Johnson KC, Wactawski-Wende J, Ravdin PM, Schenken R, Hendrix SL, Rajkovic A, Rohan TE, Yasmeen S, Prentice RL, Investigators WHI (2010) Estrogen plus progestin and breast cancer incidence and mortality in postmenopausal women. JAMA. 304(15):1684-1692. https://doi.org/10.1001/jama.2010.1500

63. Beral V, Million Women Study C. Breast cancer and hormonereplacement therapy in the Million Women Study. Lancet. 2003;362(9382):419-427. doi: https://doi.org/10.1016/s01406736(03)14065-2
64. Greendale GA, Palla SL, Ursin G, Laughlin GA, Crandall C, Pike MC, Reboussin BA (2005) The association of endogenous sex steroids and sex steroid binding proteins with mammographic density: results from the postmenopausal estrogen/progestin interventions mammographic density study. Am J Epidemiol 162(9):826834. https://doi.org/10.1093/aje/kwi286

65. Moyer DL, Felix JC, Kurman RJ, Cuffie CA (2001) Micronized progesterone regulation of the endometrial glandular cycling pool. Int J Gynecol Pathol 20(4):374-379. https://doi.org/10.1097/ 00004347-200110000-00010

66. Lane G, Siddle NC, Ryder TA, Pryse-Davies J, King RJ, Whitehead MI (1983) Dose dependent effects of oral progesterone on the oestrogenised postmenopausal endometrium. Br Med J (Clin Res Ed) 287(6401):1241-1245. https://doi.org/10.1136/bmj.287.6401. 1241

67. Fournier A, Dossus L, Mesrine S, Vilier A, Boutron-Ruault MC, Clavel-Chapelon F, Chabbert-Buffet N (2014) Risks of endometrial cancer associated with different hormone replacement therapies in the E3N cohort, 1992-2008. Am J Epidemiol 180(5):508-517. https://doi.org/10.1093/aje/kwu146

68. Casey AE, Sinha A, Singhania R, Livingstone J, Waterhouse P, Tharmapalan P, Cruickshank J, Shehata M, Drysdale E, Fang H, Kim H, Isserlin R, Bailey S, Medina T, Deblois G, Shiah YJ, Barsyte-Lovejoy D, Hofer S, Bader G, Lupien M, Arrowsmith C, Knapp S, De Carvalho D, Berman H, Boutros PC, Kislinger T, Khokha R (2018) Mammary molecular portraits reveal lineagespecific features and progenitor cell vulnerabilities. J Cell Biol 217(8):2951-2974. https://doi.org/10.1083/jcb.201804042

Publisher's Note Springer Nature remains neutral with regard to jurisdictional claims in published maps and institutional affiliations. 